\title{
PELATIHAN PENYEGARAN MATERI AJAR MATEMATIKA BAGI GURU SD KELAS RENDAH DI KECAMATAN TABANAN
}

\author{
Gst Ayu Mahayukti 1,*, Djoko Waluyo ${ }^{2}$, Wayan Sadra ${ }^{3}$ \\ 1 Jurusan Pendidikan Matematika. Universitas Pendidikan Ganesha, Indonesia \\ 2 Jurusan Pendidikan Matematika. Universitas Pendidikan Ganesha, Indonesia \\ 3 Jurusan Pendidikan Matematika. Universitas Pendidikan Ganesha, Indonesia
}

\begin{abstract}
Abstrak
Tujuan utama dari kegiatan ini adalah meningkatkan penguasaan materi ajar matematika bagi guru-guru SD di kecamatan Tabanan. Kegiatan ini dilaksanakan dalam bentuk pelatihan/diklat. Materi diklat meliputi materi ajar matematika untuk kelas rendah (2-3), yang meliputi konsep bilangan dan pecahan serta operasinya. Prosedur evaluasi untuk menilai keberhasilan kegiatan yang dilakukan adalah sebagai Pre-test dan post test dan Observasi. Kegiatan dikatakan berhasil jika minimal $85 \%$ sasaran hadir, dan minimal $85 \%$ peserta hadir yang hadir mengikuti secar penuh. Dari hasil tes terkait bilangan bulat dan pecahan diperoleh bahwa tingkat penguasaan materi guru lumayan baik, karena rata-rata skor test terendah adalah 72 dan peserta yang hadir 23 orang dari 25 orang yang diundang (lebih dari 85\%). Respon guru terhadap materi yang disajikan sangat tinggi, ini ditunjukkan oleh antusias guru mengajukan permasalahan dan memberikan tanggapan jika diberikan permasalahan.
\end{abstract}

Keywords:

Pelatihan, Materi Ajar

Matematika, Guru SD

\section{Pendahuluan}

Para pakar pendidikan seringkali menegaskan bahwa guru merupakan sumber daya manausia yang sangat menentukan keberhasilan program pendidikan. Apapun yang telah dilakukan untuk meningkatkan mutu pendidikan tidak mungkin ada tanpa peningkatan kualitas performansi gurunya (Mendiknas, 2013). Oleh karenanya dalam menjawab tantangan di zaman globalisasi, peningkatan kualitas performansi guru mutlak harus dilakukan secara terus menerus dalam rangka peningkatan mutu pendidikan. Hal ini mengisyaratkan betapa pentingnya keberadaan seorang guru yang mampu mengelola proses belajar mengajar secara profesional. Keberadaan guru di sekolah atau ditengah-tengah masyarakat sangat diharapkan sebagai salah satu unsur yang tidak hanya dapat dijadikan teladan, tetapi juga dapat senantiasa mengikuti derap perkembangan zaman. Seorang guru dituntut senantiasa dapat memberi jawaban yang memuaskan atas pertanyaan yang diajukan siswanya dan memberikan jalan keluar. Oleh karena itu dituntut dapat menyesuaikan diri dengan segala proses perubahan yang terjadi pada saat dan kurun waktu, baik di lingkungan sekolah maupun di lingkungan masyarakat.

Adanya melaksanakan tes UKG oleh pemerintah mulai tahun 2015 untuk guru-guru penerima dana sertifikasi ataupun untuk guru yang belum menerima dana tersebut sudah membuat para guru kelimpungan. Hal itu wajar mengingat dari tes yang dilakukan Depdiknas Tahun 2002/2003 diperoleh data bahwa ditinjau dari kelayakan mengajar ada 49,3 \% guru SD yang tidak layak mengajar dan jika ditinjau dari tes permata uji diperoleh data bahwa dari 100 soal yang diujikan kepada guru SD, masih terdapat guru yang hanya mampu menjawab hanya 5 soal dan maksimal 77 soal. Untuk guru matematika dari 40 soal yang diujikan, masih terdapat guru yang hanya mampu menjawab hanya 2 soal dan maksimal hanya mampu menjawab 36 soal. Ditinjau dari tugas pokoknya, guru adalah konservatif. Dalam arti, sukar menerima perubahan dan pembaharuan dalam proses belajar mengajar. Setiap ada perubahan kurikulum, setiap ada pembaharuan system pembelajaran hampir semua guru mengeluh karena terpaksa harus mempelajari materi yang baru, mengganti satuan pelajaran, membuat soal-soal baru dan lain sebagainya (Anom, 1998).

Subagia (2006) menungkapkan bahwa, salah satu kemampuan yang dituntut harus dimiliki seorang guru adalah kemampuan penguasaan materi pelajaran. Adanya tes UKG merupakan tantangan

* Corresponding author.

E-mail Addresses ayumahayukti@yahoo.com (Gst Ayu Mahayukti), Waluyo24@yahoo.com (Djoko Waluyo), wayansandra@yahoo.com (Wayan Sadra), 
tersendiri yang dihadapi oleh kalangan guru khususnya bagi guru-guru di kabupaten Tabanan. Di sisi lain, para guru nampaknya belum dipersiapkan untuk menghadapi hal tersebut baik oleh pemerintah daerah maupun pemerintah pusat. Di samping itu, para guru nampaknya sudah lama tidak memperoleh penyegaran materi ajar, padahal penguasaan terhadap materi ajar khususnya matematika sangat membantu dalam menghadapi tes UKG tersebut. Di samping itu juga pelatihan ini membantu guru untuk menambah wawasan guru untuk lebih memahami konsep-konsep atau prinsip-prinsip matematika yang selama ini masih ada yang salah konsep, seperti konsep perkalian yang menjadi perbincangan hangat di media sosial. Dari kegiatan pelatihan ini nantinya guru dapat membantu siswa dalam memahami konsepkonsep matematika. Salah satu kemampuan dasar yang secara subtantif minimal dikuasai oleh guru dalam mengikuti tes UKG tersebut adalah penguasaan materi ajar.

Kabupaten Tabanan sebagai salah satu kabupaten dari 9 kabupaten/kota yang ada di Propinsi Bali, memiliki visi dan misi pembangunan yang berorientasi pada sektor pertanian, pendidikan dan kesehatan. Di kecamatan Tabanan terdapat 53 SD dengan jumlah guru sebanyak 674 orang. Rata-rata kualifikasi guru SD yang ada adalah setingkat D II PGSD dan ada 560 orang guru yang sudah sarjana tetapi tidak dalam bidang studi matematika. Dalam rangka meningkatkan kualifikasi dan profesionalisme guru pemerintah kecamatan maupun kabupaten telah mengalokasikan dana untuk membantu guru melanjutkan studi baik reguler lewat UT maupun swasta. Di samping itu, untuk penyegaran wawasan dan pengetahuan para guru SD, pemerintah daerah melalui Dinas Pendidikan pemuda dan Olahraga Kabupaten Tabanan telah memprogramkan secara periodik dan berkesinambungan untuk mengirimkan para guru untuk ikut penataran atau pelatihan dan mendatangkan pakar dan profesional dari luar kabupaten baik yang berasal dari LPTK maupun lembaga pendidikan lainnya yang terkait, hanya beberapa guru yang dikirim untuk mengikuti pelatihan kare terbatas anggaran.

Pada pelaksanaan ujian akhir nasional untuk jenjang SD rata-rata nilai yang diperoleh pada mata pelajaran matematika senantiasa sangat rendah. Rendahnya prestasi belajar yang diperoleh siswa, sampai saat ini masih menjadi sorotan dari banyak pihak di masyarakat. Selanjutnya, kecamatan Tabanan sangat potensial untuk dikembangkan dalam berbagai aspek. Dalam bidang pendidikan, diperoleh informasi bahwa, masih banyak yang perlu dibenahi terkait dengan kualitas pendidikan di kelurahan dan desa tersebut termasuk kualitas pendidikan matematika di SD. Keadaan ini perlu mendapat kajian yang mendalam bagi kalangan praktisi pendidikan untuk mengetahui faktor-faktor penyebabnya serta mencari solusinya. Di samping itu kegiatan yang berkaitan dengan penataran ataupun pelatihan terkait penyegaran materi ajar sangat jarang diadakan. Hal ini juga dikuatkan hasil angket yang disebarkan di akhir kegiatan P2M tahun 2014 dimana 60 \% guru minta kegiatan P2M tersebut dilanjutkan terutama membahas permasalahan dalam pembelajaran materi ajar matematika khususnya topik-topik yang sulit diajarkan guru di kelas, hal di atas juga ditunjang oleh surat permintaan dari Kepala UPTD kecamatan Tabanan yang memohon agar kegiatan P2M ini bisa dilanjutkan pada tahun berikutnya (lampiran 01). Sehingga hal tersebut nampaknya layak dijadikan salah satu tema atau fokus kegiatan, karena sifatnya aktual-faktual dan prediktif perbaikan mutu pendidikan SD di kecamatan Tabanan

Kepala UPTD kecamatan Tabanan menyatakan bahwa mereka sangat mengharapkan agar guruguru khususnya di eklas rendah dapat diberikan penataran atau pelatihan penyegaran materi ajar dan juga telah menyatakan kesanggupannya untuk menyediakan tempat maupun fasilitas-fasilitas yang diperlukan dalam pelatihan tersebut.. Berdasarkan analisis situasi di atas, maka permasalahan dari kegiatan pengabdian pada masyarakat ini adalah masih rendahnya penguasaan guru-guru SD di Kecamatan Tabanan pada materi ajar matematika.

Tujuan utama dari kegiatan ini adalah meningkatkan penguasaan materi ajar matematika bagi guru-guru SD di kecamatan Tabanan. Hasil kegiatan pengabdian pada masyarakat ini memberikan kontribusi positif terhadap usaha peningkatan kualitas pendidikan, khususnya pendidikan matematika di jenjang SD. Secara eksplisit kontribusi hasil kegiatan pengabdian masyarakat ini dapat dijabarkan sebagai berikut. a) Para guru SD peserta pelatihan mendapatkan wawasan baru terkait penguasaan materi ajar matematika, diharapkan pula bahwa pengalaman itu dapat ditularkan kepada guru sejawat. b) Bagi Dinas Pendidikan dan kebudayaan di Kabupaten Tabanan, program ini dapat membantu merealisasikan salah satu program yang telah disusun dalam rencana pembangunan pendidikan di Tabanan, khususnya pada jenjang SD. Undiksha, program ini sangat bermanfaat dalam menjalin kerjasama yang mutualistis antara LPTK dengan kalangan masyarakat luas, sehinnga tenaga dan bergagai potenssi yang ada dapat disumbangkan kepada kalayak luas khususnya yang berkenan dengan sektor pendidikan.

\section{Metode}

Sebagaimana telah diuraikan di atas bahwa muara dari kegiatan ini adalah untuk meningkatkan kualitas pembelajaran, khususnya penguasaan guru terhadap materi ajar matematika di SD. Terkait 
dengan hal ini, khalayak sasaran yang strategis dan tepat untuk dilibatkan dalam kegiatan ini adalah guruguru SD kelas rendah. Dalam kegiatan pengabdian periode ini sebagai khalayak sasaran ditetapkan guruguru SD di Gugus 3 dan 4 kecamatan Tabanan, yang mana ada 5 SD di Gugus 3 dan 6 SD di Gugus 4, masing SD akan dilibatkan 2 guru, 1 orang kepala K2S dan 2 orang pengawas sehingga total peserta adalah 25 orang.

Kegiatan ini dilaksanakan dalam bentuk pelatihan/diklat. Materi diklat meliputi materi ajar matematika untuk kelas rendah (2-3), yang meliputi konsep bilangan dan pecahan serta operasinya. Prosedur evaluasi untuk menilai keberhasilan kegiatan yang dilakukan adalah sebagai berikut. Pre-test dan post test dan Observasi. Observasi selama pelatihan untuk mengetahui aktivitas dan antusiasme para peserta pelatihan dalam mengikuti kegiatan. Ada dua aspek yang dievaluasi pada kegiatan ini. Aktivitas peserta selama pelatihan berlangsung. Keberhasilan dapat dilihat dari kehadiran dan aktivitas peserta selama kegiatan baik bertanya, menjawab pertanyaan dan berdiskusi. Kegiatan dikatakan berhasil jika minimal 85\% sasaran hadir, dan minimal 85\% peserta hadir yang hadir mengikuti secar penuh. Tingkat penguasaan materi. Keberhasilan dilihat dari skor perolehan pada post test, yakni jika tergolong tuntas, yaitu rata-rata skor post test minimal 70 dengan minimal $85 \%$ peserta skornya lebih dari 70 . Pendampingan Pasca pelatihan dilakukan pendampingan untuk melihat bagaimana guru mengimplementasikan hasil pelatihan. Pendampingan dilakukan sekali yang dilaksanakan 3 minggu setelah pelatihan dan diambil dua sekolah di masing- masing Gugus (SD 3 Dajan Peken dan SD 5 Gubug).

\section{Hasil Dan Pembahasan}

Pelaksanaan kegiatan pengabdian kepada Masyarakat "Pelatihan Penyegaran Materi Ajar Matematika bagi Guru-Guru SD di kecamatan Tabanan” melibatkan masing- masing 2 orang guru kelas rendah (I, II dan III) di Gugus 3 dan 4 kecamatan Tabanan, yang mana ada 5 SD di Gugus 3 dan 6 SD di Gugus 4, 1 orang ketua K2S dan 2 orang pengawas sehingga total peserta adalah 25 orang. Hampir semua kegiatan telah terlaksana yakni 1) penyusunan materi pelatihan berupa "operasi bilangan bulat dan pengenalan konsep pecahan dan pembelajarannya," 2) pelaksanaan pelatihan penyegaran materi ajar matematika yang diberikan oleh bapak I Made Suarsana, S.Pd, M.Si. Hasil pelaksanaan masing-masing sub kegiatan dapat dipaparkan sebagai berikut.

Materi pelatihan meliputi operasi bilangan bulat, pengenalan konsep bilangan pecah dan pembelajarannya. Untuk materinya lebih banyak mengadopsi materi buku pegangan siswa dan pembelajarannya mengadopsi dari pendidikan matematika III (diktat PGSM). Kegiatan "Pelatihan Penyegaran Materi Ajar Matematika Bagi Guru SD kelas Rendah di kecamatan Tabanan" yang dilaksanakan pada hari Sabtu tanggal 23 Juli 2016. Dari 25 orang guru yang diundang hanya 23 orang yang hadir, dan yang tidak hadir 2 orang karena sedang mengikuti kegiatan pelatihan yang sejenis. Adapun susunan acara pelaksanaan penyegaran materi ajar matematika sebagai berikut.

Table 1 daftar kegiatan pelatihan

\begin{tabular}{cl}
\hline Waktu & Kegiatan \\
\hline $08.00-08.30$ & Pembukaan \\
$08.30-10.00$ & Pemaparan makalah \\
$10.00-11.00$ & Diskusi \\
$11.00-12.30$ & Latihan Soal-soal dan tanya Jawab \\
$12.30-13.00$ & Istirahat makan siang \\
13.00 & Penutup \\
\hline
\end{tabular}

Dari hasil tes terkait bilangan bulat dan pecahan diperoleh bahwa tingkat penguasaan materi guru lumayan baik, karena rata-rata skor test terendah adalah 72 dan peserta yang hadir 23 orang dari 25 orang yang diundang (lebih dari 85\%). Respon guru terhadap materi yang disajikan sangat tinggi, ini ditunjukkan oleh antusias guru mengajukan permasalahan dan memberikan tanggapan jika diberikan permasalahan. Dari tugas kerja kelompok yang diberikan hasilnya juga baik karena cuma satu kelompok yang kurang lengkap dan masih ada kesalahan, begitu juga saat diskusi kelompok mereka sangat serius dan kompak dan saat tanya jawab dengan nara sumber juga sampai melebihi waktu yang direncanakan. Angket yang diedarkan juga memberikan respon yang positif dan $75 \%$ mengharapkan kegiatan ini bisa dilanjutkan secara berkesinambungan dan berkelanjutan.

Pendampingan dilakukan sekali dan yang dilaksanakan tanggal 26 Agustus 2016 di SD 3 Dajan Peken dan SD 5 Gubug. Guru SD 4 Gubug yang didamping adalah ibu Ni Wayan Mariati dan Ni Made Widiari guru SD 2 Sudimara. Pada saat pedampingan kepala sekolah juga turut serta mendampingi 
sehingga guru menjadi lebih bersemangat dan banyak mendiskusikan hal-hal yang ditemui saat mengajar seperti kurangnya alat peraga yang murah dan mudah digunakan untuk menjelaskan konsep pecahan dan operasi bilangan bulat. Demikian juga dalam dalam penanaman konsep perkalian,guru kebingungan karena siswa sering lupa hasil kali dua buah bilangan, ataupun hasil bagi dua buah bilangan misal

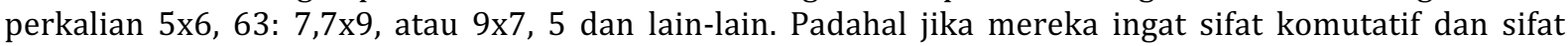
pembagian pasti mereka mudah untuk memahami hal tersebut. Mereka juga mempertanyakan mungkan tidak guru kembali menerapkan sistem driil untuk siswanya khususnya untuk perkalian agar konsepkonsep dikuasai dan diingat lama oleh siswa, karena tidak semua siswa dapat mengkostruksi sendiri pengetahuannya. Kegiatan "Pelatihan Penyegaran Materi Ajar Matematika bagi Guru-Guru SD di kecamatan Tabanan berlangsung sesuai rencana dan guru sangat antusias selama mengikuti pelatihan, dan respon mereka juga sangat positif. Kegiatan ini dirasakan sangat besar manfaatnya bagi peserta. Hal ini didukung oleh jawaban peserta terhadap angket yang diberikan pada akhir pelatihan. Kegiatan ini juga dipandang perlu dan penting oleh peserta. Hal ini terlihat dari keantusiaan dan ketekunan peserta saat pemaparan materi dari nara sumber, keaktifan peserta dalam diskusi kelompok dan tanya jawab.

Jumlah peserta yang hadir juga melebihi target minimal yang direncanakan, ini berarti kerjasama Ka. UPTD, pengawas, K3S dan Undiksha sangat bagus. Berdasarkan hasil tes, hasil observasi dan respon peserta terhadap angket yang disebarkan dapt disimpulkan bahwa secara keseluruhan kegiatan P2M ini berhasil.

\section{Simpulan Dan Saran}

Beberapa kesimpulan yang dapat dibuat dari kegiatan ini adalah 1) Setelah mengikuti pelatihan ini guru kelas rendah mendapatkan pencerahan dalam mengatasi permasalah dalam pembelajaran konsep bilangan bulat dan pecahan. Materi ini sangat bermanfaat bagi guru untuk melaksanakan pembelajaran, memberi penguatan bagi siswanya. 2) Setelah mengikuti pendampingan beberapa permasalah di kelas bisa langsung divarikan solusinya karena narasumber langsung mendampingi di kelas. 3) Kegiatan pelatihan ini dipandang sangat bermangfaat dan diperlukan bagi guru-guru dan mereka berkeinginan kegiatan semacam ini berlangsung secara berkelanjutan dan berkesinambungan. Perlu dilakukan pelatihan dengan waktu yang lebih panjang (2-3) hari, sehingga peserta dapat lebih banyak mempraktekan materi yang didapatkan. Perlu dilakukan kegiatan pelatihan yang berlangsung secara berkelanjutan dan berkesinambungan. Perlu pendampingan ke sekolah-ke sekolah yang lebih banyak sehingga guru lebih siap di kelas.

\section{Daftar Pustaka}

Anom, Ida Bagus, 1998. Upaya pengikatan Profesionalisme Guru IPA pada Era Globalisasi Suatu Tantangan Perubahan. Makalah. Disampaikan dalam Seminar Profil Guru MIPA dalam Meningkatkan Sumber Daya Manusia yang Berwawasan Ilmu Pengetahuan dan Teknologi serta Iman dan Taqwa di MIPA STKIP Singaraja tanggal 19 Januari 1998. Bali: Depdikbud.

Kementerian Pendidikan dan Kebudayaan. 2012. Kebijakan Pengembangan Profesi Guru. Jakarta: Badan PSDMPK-PMP.

Kementerian Pendidikan dan Kebudayaan.2013. Materi Diklat Pelatihan Implementasi Kurikulum 2013 Sekolah Dasar. Jakarta: Badan PSDMPK-PMP.

Sumarna Surapranata. 2006. Kualifikasi, Kompetensi dan Sertifikasi Pendidik. Makalh. Disampaikan dalam Seminar Nasional pendidikan di IKIP Negeri Singaraja tanggal 1 Februari 2006. Jakarta: Dikti Depdiknas.

Subagia, I Wayan. 2006. Pengembangan Kompetensi Pedagogik dalam Kurikulum Pendidikan Guru Pemula. Makalah. Disampaikan pada Seminar Pengembanangan Kurikulum Pendidikan MIPA Menyongsong Sertifikasi Guru di FPMIPA IKIP Negeri Singaraja, 22 April 2006. Singaraja: FPMIPA IKIP Negeri Singaraja. 